\title{
Phlebotomines (Diptera, Psychodidae) in the Speleological Province of the Ribeira Valley: 3. Serra district - area of hostels for tourists who visit the Parque Estadual do Alto Ribeira (PETAR), state of São Paulo, Brazil
}

\author{
Eunice Aparecida Bianchi Galati ${ }^{1}$, Ana Maria Marassá2 ${ }^{2}$, Mauro Breviglieri Fonseca ${ }^{1}$, \\ Rute Maria Gonçalves-Andrade ${ }^{3}$, Cleide Aschenbrenner Consales ${ }^{4} \&$ Edna Fátima Maria Bueno ${ }^{1}$
}

\begin{abstract}
'Departamento de Epidemiologia, Faculdade de Saúde Pública, Universidade de São Paulo. Av. Dr. Arnaldo 715, 01246-904 São Paulo-SP, Brazil. egalati@usp.br

${ }^{2}$ Post-graduate student of the Faculdade de Saúde Pública and Secção de Parasitoses Sistêmicas, Instituto Adolpho Lutz. Av. Dr. Arnaldo 355, 01246-904 São Paulo-SP, Brazil. anamarassa@usp.br

${ }^{3}$ Laboratório de Imunoquímica, Instituto Butantan. Av. Vital Brasil 1500, 05508-900 São Paulo-SP, Brazil. rutemgdeandrade@butantan.gov.br

4nstituto Pasteur. Av. Paulista 393, 01311-000 São Paulo-SP, Brazil. cleide135@yahoo.com.br
\end{abstract}

\begin{abstract}
Phlebotomines (Diptera, Psychodidae) in the Speleological Province of the Ribeira Valley: 3. Area of hostels for tourists who visit the Parque Estadual do Alto Ribeira (PETAR), state of São Paulo, Brazil. The study characterizes some ecological aspects of the phlebotomine fauna in an endemic area of cutaneous leishmaniasis (CL) situated in the Serra district, Iporanga municipality where the hostels for tourists visiting the PETAR are located. Captures were undertaken on a smallholding and a small farm situated near the hostels, monthly between January/2001 and December/2003 with automatic light traps (ALT) in pigsty, henhouse and veranda of a domicile at the two sites, and in peridomicile of the small farm also with black/white Shannon traps. With the ALT a total of 87,224 phlebotomines representing 19 species and also two hybrids of Nyssomyia intermedia (Lutz \& Neiva) and Nyssomyia neivai (Pinto) and two anomalous specimens were captured. The standardized index species abundance was for $N y$. intermedia $=1.0$ and $N y$. neivai $=0.935$. The highest frequencies of the smallholding occurred in the pigsty, the Williams' mean/ capture for $N y$. intermedia being 63.7 specimens and for $N y$. neivai 29.2, and on the small farm, in the hen-house, $N y$. intermedia 402.6 and $N y$. neivai 116.2. A total of 863 phlebotomines ( $N y$. intermedia: $75.4 \% ; N y$. neivai: $24.3 \%$ ) were captured with black/ white Shannon traps; females of both species being predominant in the white trap. The high frequencies of $N y$. intermedia and $N y$. neivai, both implicated in CL transmission, indicate the areas presenting risk of the disease.
\end{abstract}

KEYWORDS. Ecology; leishmaniases; Lutzomyia longipalpis; Phlebotominae; vectors.

RESUMO. Phlebotominae (Diptera, Psychodidae) na Província Espeleológica do Vale do Ribeira: 3. Área de pousadas para turistas que visitam o Parque Estadual do Alto Ribeira (PETAR), estado de São Paulo, Brasil. O estudo teve como objetivo caracterizar alguns aspectos ecológicos da fauna flebotomínea em área endêmica de leishmaniose tegumentar situada do Bairro Serra, município de Iporanga, onde se situam pousadas para turistas que visitam o PETAR. As capturas foram realizadas em uma chácara e em um sítio, mensalmente, entre janeiro de 2001 e dezembro de 2003, com armadilhas automáticas luminosas (AAL) em chiqueiro, galinheiro e varanda do domicílio de ambos os locais, e no sítio, também com armadilhas de Shannon branca/preta. Capturou-se com as AALs um total de 87.224 flebotomíneos, representando 19 espécies, mais dois híbridos de Nyssomyia intermedia (Lutz \& Neiva, 1912) e Nyssomyia neivai (Pinto, 1926) e dois espécimes anômalos. Ny. intermedia apresentou o índice de abundância das espécies padronizado $=1,0$ e $N y$. neivai $=0,935$. Na chácara, ambas predominaram no chiqueiro, com a média geométrica de Williams/captura para $N y$. intermedia $=63,7$ espécimes e para $N y$. neivai $=29,2$, e no sítio, no galinheiro, $N y$. intermedia $=402,6 \mathrm{e}$ Ny. neivai $=116,2$. Capturou-se nas armadilhas de Shannon branca/preta 863 flebotomíneos: $N y$. intermedia $(75,4 \%)$ e $N y$. neivai $(24,3 \%)$, as fêmeas sendo significativamente predominantes na branca. As altas freqüências de $N y$. intermedia e $N y$. neivai, ambas implicadas na transmissão de agente da leishmaniose tegumentar, indicam risco de transmissão da doença na área.

PALAVRAS-CHAVE. Ecologia; leishmanioses; Lutzomyia longipalpis; Phlebotominae; vetores.

The phlebotomines are a group of insects found in many regions of the world, about 500 species of them occurring in the Americas, half of them in Brazil and about 68 in São Paulo state (Galati 2003a). Both sexes need sugar in their diet, but only the females are considered haematophagous, biting a large spectrum of vertebrates: mammals, birds and cold blooded animals (Tesh et al. 1972; Morrison et al. 1993a). The haematophagic activity is predominantly nocturnal (Forattini 1973), but they also bite during the day (Gomes et al. 1989; Galati et al. 2006). Many species are anthropophilic, causing bothersome bites, and may transmit pathogens, including the agents of cutaneous and visceral leishmaniases to humans (Sherlock 2003). These diseases represent a serious public health problem, with growing incidences and distribution, covering also metropolitan areas (Desjeux 2004; Camargo \& Langoni 2006).

Although the phlebotomines are frequently associated with forests, they are also found in areas with no vegetation cover, including urban areas and caves. Their breeding places occur in moist soil, without direct sunlight, rich in organic material, situated among exposed roots, under fallen leaves and rocks, in animal dens and anthropic environments, in 
pigsties, hen-houses and other ecotopes in which conditions are appropriate (Forattini 1973). The resting places of adults may be the same sites as their breeding places or in holes, on tree trunks, leaves of bushes or under fallen leaves. Both sexes tend to stay close to their resting places. Studies using markrelease-recapture techniques have demonstrated that although some specimens may be recaptured up to almost $1 \mathrm{~km}$ away from the release point, the greater part are recaptured within 200 m (Alexander 1987; Morrison et al. 1993b; Casanova et al. 2005; Galati et al. 2009).

Of the 244 phlebotomine species occurring in Brazil, at least $47(19.3 \%)$ of them have been found in caves (Galati et al. 1997, Andrade Filho et al. 2001; Aguiar \& Medeiros 2003; Galati et al. 2003a; Alves 2007) and in accordance with Galati's (2003a) nomenclature they belong to the genera Bichromomyia, (1 species) Brumptomyia (4), Deanemyia (3), Edentomyia (1),Evandromyia (7), Lutzomyia (8), Martinsmyia (1), Micropygomyia (6) Migonemyia (1), Nyssomyia (3), Pintomyia (3), Psathyromyia (4), Psychodopygus (1) Trichophoromyia (1) and Sciopemyia (3). It is probable that some of them use the caves as resting places, as in the case of those of Brumptomyia and Psathyromyia, closely associated with armadillo burrows (Forattini 1973; Young \& Duncan 1994), as well as Migonemyia, Nyssomyia, Psychodopygus, Trichophoromyia and some species of Pintomyia and Psathyromyia that are associated with forests (Aguiar \& Medeiros 2003). Some species are troglophiles (Galati et al. 2003a) and the endemic, parthenogenetic and autogenic Deanemyia maruaga (Alves, Freitas \& Barret, 2008) (Alves et al. 2008) can be identified as a troglobite species.

Among the troglophile species are vectors of the visceral leishmaniasis agent, Lutzomyia longipalpis (Lutz \& Neiva, 1912) being the main one in Latin America, Lu cruzi (Mangabeira, 1938) and Lu. forattinii Galati, Rego Jr., Nunes \& Teruya, 1985, in areas of the Pantanal, Mato Grosso do Sul State (Galati et al. 1997; Santos et al. 1998; Pita-Pereira et al. 2008) and Lutzomyia almerioi Galati \& Nunes, 1999 (Savani et al. 2009) in the Serra da Bodoquena, in the same State.

The phlebotomine vectors of the cutaneous leishmaniasis agents according to Galati's (2003a) classification belong to several genera: Bichromomyia, Lutzomyia, Migonemyia, Nyssomyia, Pintomyia, Psychodopygus and Trichophoromyia, which habitats are forests, however, some species are also abundant in peridomestic environments in deforested rural areas (Lainson \& Shaw 2005). In the Brazilian Southeast region Nyssomyia whitmani (Antunes \& Coutinho, 1939), Nyssomyia intermedia (Lutz \& Neiva, 1912) and Ny. neivai (Pinto, 1926) are the main phlebotomines implicated as vector of cutaneous leishmaniasis agent (Rangel \& Lainson 2003; Andrade Filho et al. 2007). These two latter species show great morphological similarity, so that $N y$. neivai was considered a junior synonym of $N y$. intermedia for more than 50 years, being resurrected by Marcondes (1996). In São Paulo state Ny. intermedia occurs in areas of the coast and $N y$. neivai within, however, they are sympatric in some areas of the Serra de Paranapiacaba (Marcondes et al. 1998; Andrade Filho et al. 2007).
The Speleological Province of the Ribeira Valley, with an area of about $11,900 \mathrm{~km}^{2}$, is situated in Southeastern Brazil, in the south of São Paulo and the north of Paraná states (Auler 2002). In the state of São Paulo, this province occupies areas largely situated in the Serra de Paranapiacaba, mainly in two forest reserves: Parque Estadual Turístico do Alto Ribeira (PETAR), with more than 300 registered caves and Parque Estadual Intervales (PEI), with about 50 caves (São Paulo 2008). Many people, attracted by the ecological tourist potential of the area due to the numerous caves, rivers, falls and the remnant of Atlantic forest, visit these parks. The lodgings for visitors to the PETAR are situated in the Serra district, Iporanga municipality, state of São Paulo.

The region of the Ribeira Valley, with a total of 1,174 cutaneous leishmaniasis cases registered between 1998 and 2006, presents one of the highest average annual coefficients of incidence in the São Paulo state: 47.71/100,000 inhabitants. This coefficient for Iporanga municipality, where the PETAR and the Serra district are situated, is 152.9/100,000 inhabitants, this being one of the highest in the Ribeira Valley region (CVE 2007).

In the Ribeira Valley, the phlebotomines have been studied in forested and/or anthropic environments (Forattini et al. 1976; Gomes et al. 1980, 1982, 1983, 1986, 1990, Gomes \& Galati 1987, 1989, Domingos et al. 1998, Taniguchi et al. 2002); but not in these parks or their adjacent areas, such as the Serra district. Thus the present authors undertook a project for the purpose of identifying the phlebotomine fauna of these two parks (Galati et al. 2010a, 2010b), including the areas of the respective lodgings, and characterizing some aspects of its behaviour. This present paper reports on the sandflies of two small farms in the Serra district, with special emphasis on the vectors of leishmaniases.

\section{MATERIAL AND METHODS}

Study area. The Serra district, $240 \mathrm{~m}$ above sea level, is situated on the banks of the Betari river, a tributary on the left bank of the Ribeira do Iguape river, in the municipality of Iporanga $\left(24^{\circ} 21^{\prime} \mathrm{S}, 48^{\circ} 20^{\prime} \mathrm{W}\right)$. This district, with about 110 dwellings (Giatti et al. 2004) is situated within a narrow strip along the road that links Iporanga and Apiaí cities, and has an economy based mainly on catering for the tourists who visit the caves of the Santana nucleus, about $4 \mathrm{~km}$ away from the principal entrance to the Santana cave. Though it is an area of environmental preservation it does not belong to the PETAR, an Atlantic forest reserve on the Serra de Paranapiacaba, in the south of São Paulo state.

The Serra district is located in a transitional area between the so-called "Atlantic Plateau" and the coastal plain. Its climate is also transitional, between a tropical low altitude one and a temperate one of intermediate altitude (Nimer 1977), and is classified as sub-tropical and highly humid with no dry season. The average annual rainfall from 1970 to 1996 was $1963.3 \mathrm{~mm}$, of which $681.8 \mathrm{~mm}$ fell in the (relatively) dry season (April -September) and 1,281.5 $\mathrm{mm}$ in the rainy season. The vegetation consists of a coastal, hygrophilous, 
non-deciduous forest, with the highest trees attaining 25-30 $\mathrm{m}$, and presents large numbers of lianas, epiphytes, tree ferns and palms (Karmann \& Ferrari 2002).

Two areas on the left bank of the Betari river were sampled: the JRA smallholding and the AG small farm, about $520 \mathrm{~m}$ from each other (Fig. 1).

On the JRA smallholding ( $c a .1 / 2 \mathrm{ha}$ ), about $50 \mathrm{~m}$ from the Betari river, there was a dwelling in which a family of four lived. In the peridomicile there was a pigsty which contained one pig when the project began, January 2001, but which was slaughtered two months later. In July 2002 a new pigsty was constructed for another pig, but in which others were housed in the following months. In November 2002 a sow produced a litter. During the whole research period there were a chickenhouse and goose-shelter close to the dwelling, on the opposite side to the pigsty. Near the dwelling there were several fruit trees and, about $30 \mathrm{~m}$ away, several old, very high native trees with holes in their trunks and bromeliads on their branches and trunks. A stream, a tributary on the left bank of the Betari river and at this point parallel to it, formed the rear limit of the smallholding, at ca. $150 \mathrm{~m}$ from the confluence of the two. Around this smallholding there were other properties of similar characteristics, and on one of them there were cattle. Between these smallholdings, located in the Betari valley, and the forested reserve (in a hilly area) about $300 \mathrm{~m}$ away, there

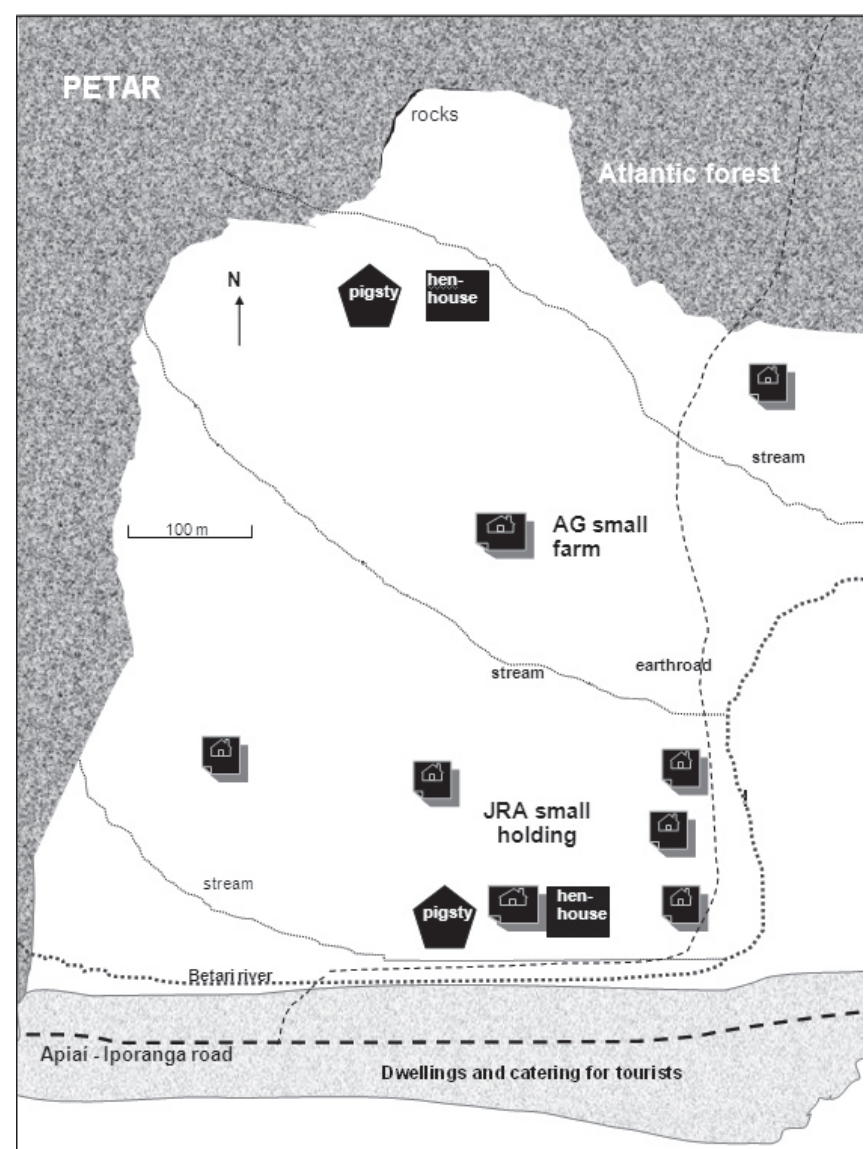

Fig. 1. Scheme of spatial position of the two localities, the AG small farm and JRA smallholding in the Serra district, Iporanga municipality. was an area where subsistence agriculture (beans, manioc, maize and other crops) was practiced.

On the AG small farm (of $c a .20$ ha.) there was a dwelling only temporarily inhabited, a hen-house and a pigsty about $85 \mathrm{~m}$ from the hen-house and some horses, until February 2003. The dwelling was permanently occupied from March to December 2003, and another pigsty, adjacent to the henhouse, was constructed and several pigs and chickens were added, as well as cows on the pasture, with a stockyard about $30 \mathrm{~m}$ from the hen-house/pigsty. The domicile is about $160 \mathrm{~m}$ from the hen-house/pigsty, with the space between occupied by an orchard and pasture. A relatively well-preserved forest covers the higher part of the slope about $100 \mathrm{~m}$ from the henhouse/pigsty and 300 from the domicile.

Methodology. The captures were carried out monthly by two different techniques: the first using automatic light traps (Natal et al. 1991) modified as follows: they have a nobreak battery (6 volts and 12 amperes) as energy source and an external collection chamber linked to the body of the trap by a sleeve, and the second using modified black and white Shannon traps (Galati et al. 2001). In the three ecotopes of the JRA smallholding the captures occurred during the period from February 2001 to December 2003. On the AG small farm, those on the veranda were made from March 2002 to December 2003 and those in the pigsty and in the hen-house from January 2002 to December 2003; however, the trap in the pigsty was found not to be working on the collection morning of April 2002 nor was that in the hen-house on the morning of May 2003, so the number of specimens captured in these collections has not been taken into consideration.

Samples of specimens captured with automatic light and Shannon traps were dissected to investigate natural infection, as described by Galati et al. (2003a). The remainder of the specimens captured, after being killed with chloroform, were conditioned in Petri dishes and kept under refrigeration until their clarification by the method described by Forattini (1973) and their identification according to Galati (2003b), redescription of some species (Andrade Filho et al. 2003) and descriptions of new species of the area (Galati et al. 2003b, 2006; Shimabukuro et al. 2007). A sample of these specimens is deposited in the collection of the Departamento de Epidemiologia of the Faculdade de Saúde Pública, USP. The nomenclature of the phlebotomines follows Galati (2003a) and the abbreviation of the generic names, Marcondes (2007).

The pluviometric data were obtained from the Serra dos Motas meteorological station (240 m a.s.1.), Iporanga municipality (SIGRH 2007) and the temperature data of the Eldorado municipality, which borders on the PETAR, from the Centro Integrado de Informações Agrometeorológicas do Instituto Agronômico de Campinas (CIIAGRO 2007).

Statistical analysis -The frequencies of the insects captured in simultaneous periods were obtained by Williams' geometric average (Haddow 1960), the formula for which is:

Williams average $=$ antilog $\left[\sum \log _{10}\left(\mathrm{y}_{1}+1\right)+\log _{10}\left(\mathrm{y}_{2}+1\right)\right.$ $\left.+\ldots \log _{10}\left(\mathrm{y}_{\mathrm{n}}+1\right) / \mathrm{N}\right]-1$; where $\mathrm{y}$ is the number of insects captured in each sample of each ecotope, and $\mathrm{N}$ the number of ecotopes. 
The abundance and diversity were obtained on the basis of the data of the captures carried out with automatic light traps. The index of species abundance (ISA) was calculated in accordance with Roberts \& Hsi (1979) whose formula is:

$\mathrm{ISA}=\mathrm{a}+\mathrm{Rj} / \mathrm{k}$

a: number of ecotopes sampled in which the species was not captured, multiplied by c;

c: for each ecotope a ranking of species varying from 1.0 to $\mathrm{N}$ (1.0 being the value of the most numerous species) was established; the greatest value obtained from this ranking of all the ecotopes, added to 1.0 , is $\mathrm{c}$.

$\mathrm{Rj}$ : sum of positions in the ranking of a given species covering all the ecotopes;

$\mathrm{k}$ : number of ecotopes sampled.

The standardized index of species abundance (SISA) as denominated by the authors quoted consists of the transformation of the values of ISA onto a scale of from 0 to 1.0 , where the most abundance species present the values which most closely approximate to 1.0 and vice-versa. The relevant formula is:

SISA $=\mathrm{c}-\mathrm{ISA} / \mathrm{c}-1$.

Shannon's Diversity Index $(\mathrm{H})$ and Pielou's Evenness Index (J) were calculated in accordance with Hayek \& Buzas (1997), whose formulae are:

$\mathrm{H}=-\sum \mathrm{p}(\ln \mathrm{p})$ and $\mathrm{J}=\mathrm{H} / \ln \mathrm{s}$

$\mathrm{p}$ : frequency of each species in a given ecotope; s: number of species in that ecotope.

Pearson's correlation coefficient (SPSS for Windows, Release 5.02 Program) was used in the search for possible correlations between the Williams' geometric average of insects captured monthly in all the ecotopes and the rainfall of the previous 30 days before the monthly capture date, as also between the Williams' average of the insects captured monthly and the average temperature for the month. The Chi squared test was used to compare the numbers of insects captured as between each two ecotopes.

\section{RESULTS}

In the two localities, JRA's smallholding and AG's small farm, in a total of six ecotopes, 87,224 specimens of phlebotomines, representing 19 species and four subtribes, were collected with automatic light traps. These taxa included: Brumptomyiina - Brumptomyia carvalheiroi Shimabukuro, Marassá \& Galati, 2007, Brumptomyia cunhai (Mangabeira, 1942), Brumptomyia nitzulescui (Costa Lima, 1932); Lutzomyiina - Evandromyia edwardsi (Mangabeira, 1941), Expapillata firmatoi (Barretto, Martins \& Pellegrino, 1956), Lutzomyia longipalpis, Migonemyia migonei (França, 1920), Migonemyia rabelloi (Galati \& Gomes, 1992), Migonemyia vaniae Galati, Fonseca \& Marassá, 2007, Pintomyia fischeri (Pinto, 1926) and Pintomyia monticola (Costa Lima, 1932); Psychodopygina - Nyssomyia intermedia, Nyssomyia neivai, Psathyromyia lanei (Barretto \& Coutinho, 1941), Psathyromyia pascalei (Coutinho \& Barretto, 1940), Psathyromyia sp., Psychodopygus ayrozai (Barretto \& Coutinho, 1940) and Psychodopygus geniculatus (Mangabeira, 1941) and Sergentomyiina - Micropygomyia petari Galati, Marassá \& Gonçalves-Andrade, 2003. A male and a female hybrid of $N y$. intermedia and $N y$. neivai (Figs. 2 and 3) and two anomalous male specimens of Nyssomyia were also captured. Each hybrid specimen presents two genital organs. A further explanation is given in the captions to Figs. 2 and 3.

Table I. Numbers of phlebotomines captured on the JRA smallholding and AG small farm, Serra district, Iporanga municipality, with automatic light traps, by species, sex and ecotope, between February 2001 and December 2003.

\begin{tabular}{|c|c|c|c|c|c|c|c|c|c|c|c|c|c|c|}
\hline \multirow{2}{*}{$\begin{array}{l}\text { Site } \\
\text { Ecotope } \\
\text { Species } \quad \text { sex } \\
\end{array}$} & \multicolumn{2}{|c|}{ veranda } & \multicolumn{2}{|c|}{$\begin{array}{l}\text { JRA smallholding } \\
\text { hen-house }\end{array}$} & \multicolumn{2}{|c|}{ pigsty } & \multicolumn{2}{|c|}{ veranda } & \multicolumn{2}{|c|}{$\begin{array}{l}\text { AG small farm } \\
\text { hen-house }\end{array}$} & \multicolumn{2}{|c|}{ pigsty } & \multicolumn{2}{|c|}{ Total } \\
\hline & $\mathrm{M}$ & $\mathrm{F}$ & M & $\mathrm{F}$ & M & $\mathrm{F}$ & $\mathrm{M}$ & $\mathrm{F}$ & M & $\mathrm{F}$ & M & $\mathrm{F}$ & $\mathrm{M}$ & $\mathrm{F}$ \\
\hline Br. carvalheiroi & - & - & - & - & - & 1 & - & 2 & - & - & - & 1 & - & 4 \\
\hline Br. cunhai & - & 2 & - & 1 & - & - & 23 & 11 & 11 & 5 & - & 3 & 34 & 22 \\
\hline Br. nitzulescui & 1 & 2 & 1 & - & 1 & - & - & - & 2 & 2 & - & - & 5 & 4 \\
\hline Ev. edwardsi & 1 & 1 & - & - & - & - & - & 2 & - & 2 & - & 2 & 1 & 7 \\
\hline Ex. firmatoi & - & 1 & - & - & 2 & 1 & - & - & 2 & 5 & 4 & 4 & 8 & 11 \\
\hline Lu. longipalpis & - & - & - & - & 2 & - & - & - & - & - & - & - & 2 & - \\
\hline Mg. migonei & 4 & 6 & 33 & 39 & 78 & 55 & 7 & 4 & 334 & 163 & 71 & 106 & 527 & 373 \\
\hline Mg. rabelloi & - & - & - & - & - & - & - & - & 7 & 2 & - & - & 7 & 2 \\
\hline Mg. vaniae & - & - & - & - & - & - & - & 1 & 4 & 2 & - & - & 4 & 3 \\
\hline Mi. petari & - & - & - & - & - & - & - & 2 & 2 & - & - & 3 & 2 & 5 \\
\hline Ny. intermedia & 277 & 715 & 1676 & 1878 & 3650 & 7676 & 3479 & 4706 & 11267 & 15435 & 3985 & 6434 & 24334 & 36844 \\
\hline Ny. neivai & 294 & 465 & 1221 & 1131 & 2282 & 4119 & 1000 & 1336 & 3953 & 4834 & 1440 & 2134 & 10190 & 14019 \\
\hline Pa. lanei & - & - & 1 & 3 & - & 4 & - & - & 2 & 2 & 2 & 1 & 5 & 10 \\
\hline Pa. pascalei & 4 & 2 & 1 & - & - & - & 2 & 1 & 5 & 6 & 1 & - & 13 & 9 \\
\hline$P a$. sp. & - & - & - & - & - & 4 & - & - & - & 2 & - & 1 & - & 7 \\
\hline Pi. fischeri & 4 & 3 & 29 & 69 & 33 & 137 & 2 & 19 & 20 & 172 & 50 & 200 & 138 & 600 \\
\hline Pi. monticola & - & - & - & - & - & - & - & 0 & - & 2 & - & 2 & - & 4 \\
\hline Ps. ayrozai & - & 1 & - & - & 1 & - & 1 & 3 & 3 & 6 & - & 2 & 5 & 12 \\
\hline Ps. geniculatus & 1 & - & - & - & 1 & - & - & 1 & 6 & 2 & - & 2 & 8 & 5 \\
\hline Total & 586 & 1198 & 2962 & 3121 & 6050 & 11997 & 4514 & 6088 & 15618 & 20642 & 5553 & 8895 & 35283 & 51941 \\
\hline
\end{tabular}



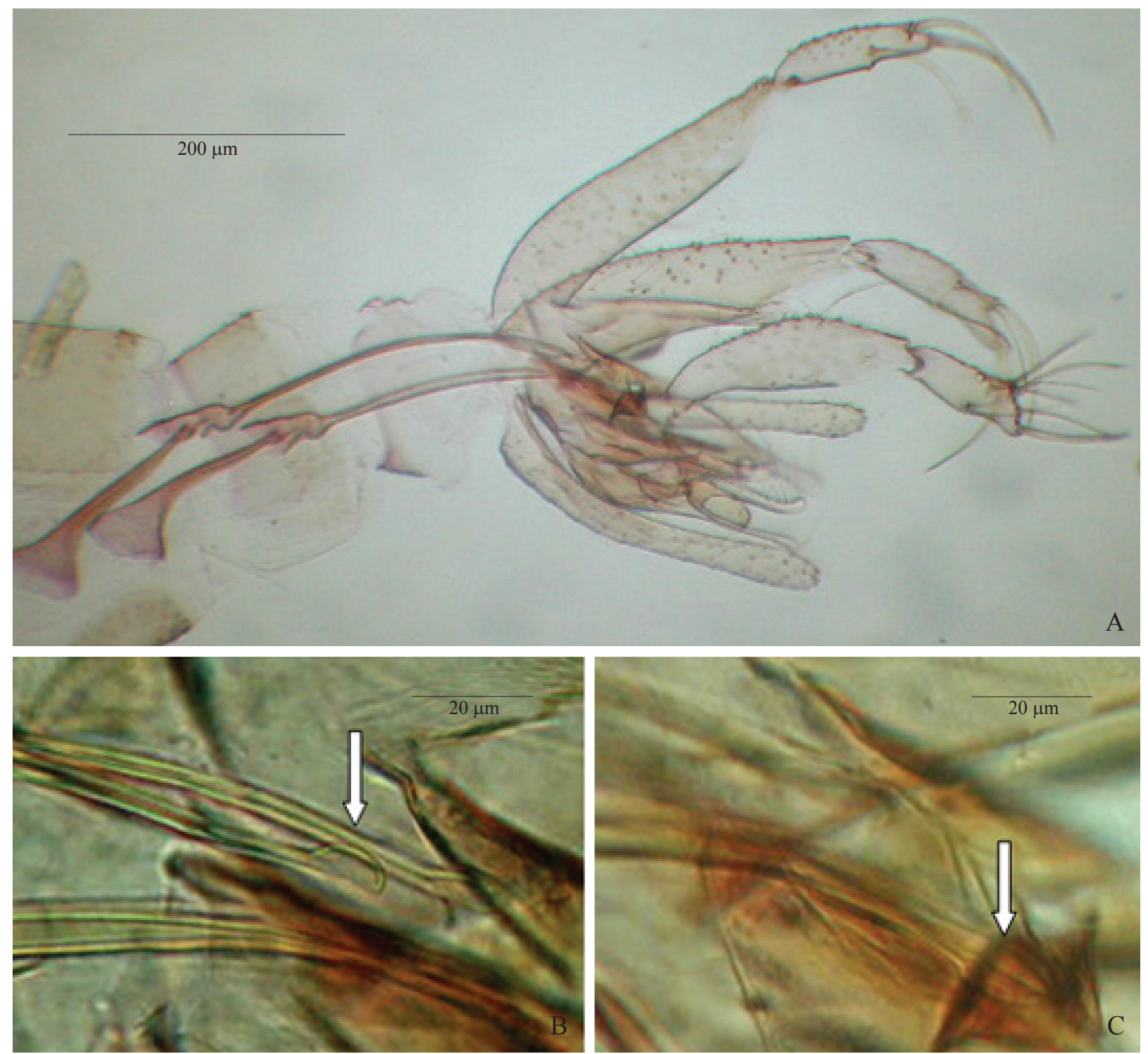

Fig. 2. Hybrid male between $N y$. intermedia and $N y$. neivai. A. terminal part of the abdomen with the two ejaculatory pumps and the respective ducts and the two terminalia. B. Ny. intermedia, the arrow showing the tip of one of the ejaculatory shaped like a ladle. C. Ny. neivai, the tips of the ejaculatory ducts like a shallow spoon or fish knife. The hybrid specimen was captured on AG small farm, Serra district (hen-house), 23/24-III-2002.

The distribution by sex of the total of specimens captured shows more females than males (female/male ratio $=1.47: 1.0$ ). Only males of $\mathrm{Lu}$. longipalpis and females of $\mathrm{Pa}$. sp. [close to Pa. pestanai (Barretto \& Coutinho, 1941)] and Pi. monticola were captured. Among the most numerous species, females of $N y$. intermedia, $N y$. neivai and Pi. fischeri were captured in greater numbers than males, female/male ratios, 1.51:1.0; 1.38:1.0 and 4.35:1.0, respectively, and males predominated in $M g$. migonei 1.0: 0.71 .

The Standardized Index of Species Abundance (SISA = 1.0) showed the absolute predominance of $N y$. intermedia in all the ecotopes. $N y$. neivai, the second most abundant, presented a SISA of 0.935 , followed by Pi. fischeri (0.839) and $M g$. migonei (0.817) (Table II).

During the simultaneous period of capture, the ecotopes of the JRA smallholding showed smaller differences, though with statistical significance $(\mathrm{p}<0.001)$; as regards the frequencies of $N y$. intermedia and $N y$. neivai, when compared with those of the AG small farm; the veranda of this latter locality has the highest $(77.7 \%$ and $22.3 \%$, respectively) and the veranda of the JRA smallholding, the lowest $(56.6 \%$ and $43.4 \%$, respectively) (Table IV).

The species richness varied from 8 to 17 . The highest species richness was observed in the hen-house of the AG small farm and the lowest in the JRA hen-house (Table III).

The highest values of Shannon's diversity $(\mathrm{H})$ and Pielou's evenness $(\mathrm{J})$ indices occurred in the hen-house $(\mathrm{H}=0.810 ; \mathrm{J}$ $=0.390)$ and on the veranda $(\mathrm{H}=0.772 ; \mathrm{J}=0.322)$ of the JRA smallholding and the lowest in the same ecotopes on the AG small farm, in the hen-house $(\mathrm{H}=0.675 ; \mathrm{J}=0.229)$ and on the veranda $(\mathrm{H}=0.583 ; \mathrm{J}=0.235)$ (Table III).

In the majority of the ecotopes, the gradient of the 
Table II. Index of Species Abundance (ISA) and Standardized Index of Species Abundance (SISA) obtained from the captures with automatic light traps in six ecotopes of the Serra district, between January 2001 and December 2003.

\begin{tabular}{lccc}
\hline Species & ISA & SISA & Position \\
\hline Ny. intermedia & 1.00 & 1.000 & $1^{\text {st }}$ \\
Ny. neivai & 2.00 & 0.935 & $2^{\text {nd }}$ \\
Pi. fischeri & 3.50 & 0.839 & $3^{\text {rd }}$ \\
Mg. migonei & 3.83 & 0.817 & $4^{\text {th }}$ \\
Br. cunhai & 7.67 & 0.570 & $5^{\text {th }}$ \\
Pa. pascalei & 9.25 & 0.468 & $6^{\text {th }}$ \\
Ps. ayrozai & 10.17 & 0.408 & $7^{\text {th }}$ \\
Pa. lanei & 10.50 & 0.387 & $8^{\text {th }}$ \\
Ps. geniculatus & 11.33 & 0.335 & $9^{\text {th }}$ \\
Br. nitzulescui & 11.50 & 0.323 & $10^{\text {th }}$ \\
Ev. edwardsi & 12.58 & 0.253 & $11^{\text {th }}$ \\
Ex. firmatoi & 13.00 & 0.223 & $12^{\text {th }}$ \\
Mi. petari & 13.67 & 0.183 & $13^{\text {th }}$ \\
Br. carvalheiroi & 13.83 & 0.172 & $14^{\text {th }}$ \\
Pa. sp. & 14.08 & 0.156 & $15^{\text {th }}$ \\
Mg. vaniae & 14.75 & 0.113 & $16^{\text {th }}$ \\
Mg. rabelloi & 15.00 & 0.097 & $17^{\text {th }}$ \\
Lu. longipalpis & 15.08 & 0.092 & $18^{\text {th }}$ \\
Pi. monticola & 15.33 & 0.075 & $19^{\text {th }}$ \\
\hline
\end{tabular}

arithmetical mean follows that of the Williams' geometrical mean, with the exception of the JRA hen-house and pigsty (Table III), to be explained by the high frequencies after July 2002, due to the reintroduction of the pigs (Fig. 4).

The monthly distributions of $N y$. intermedia and $N y$. neivai in the three ecotopes of the JRA smallholding are presented in Fig. 4. Within each graph are presented, on a small scale, by ecotope, the numbers of specimens captured from February 2001 to August 2002, when they were less numerous. In the graph of the pigsty the arrow indicates the month in which the pigs were introduced, July 2002; after two months, in September 2002, the number of specimens of $N y$. intermedia and $N y$. neivai increased; and they (especially those of the former) increased still further in October 2002. Other, though smaller, peaks of the two species occurred in March 2003, June 2003 and September 2003, and the highest number of specimens was captured in December 2003; for $N y$. intermedia the value was slightly greater but without statistical significance $\left(\chi^{2}=3.26\right.$; $\left.p>0.05\right)$; however, for $N y$. neivai it was significantly greater $\left(\chi^{2}=1047.3 ; \mathrm{p}<\right.$ 0.001 ) than that of October 2002. Two peaks occurred for the two species in the period from February 2001 to August 2002, i.e. in June 2001 and July 2002. On the veranda the density of the two species followed the same tendency as the pigsty; however, the first great peak occurred in September 2002 and the December peak was smaller, and that for $N y$. neivai exceeded that for $N y$. intermedia, although without statistical significance $\left(\chi^{2}=1.36 ; p>0.05\right)$. In the hen-house the September 2002 and March 2003 peaks were low, but in that for December both species were very numerous. From February 2001 to April 2002 the tendency was similar to that of the other two ecotopes; however, on July 2002 a peak was observed (Fig. 4).
The monthly distributions in the three ecotopes on the AG small farm show distinct patterns (Fig. 5). On the veranda the highest peak occurred in the first month of the captures, March 2002, with a clear predominance of both sexes of $N y$. intermedia, other small peaks occurring at about two-monthly intervals, the females of this species generally predominating. In the pigsty a single conspicuous peak occurred in September 2002 with a predominance of females of both $N y$. intermedia and $N y$. neivai. Other small peaks occurred at four-monthly intervals. In the hen-house, as on the veranda, the highest peak occurred in March 2002, the females of Ny. intermedia predominating over the males; a peak coincident with that of the pigsty which occurred in September 2002, Ny. intermedia females also predominating. In a third peak, in December 2002 , males of $N y$. intermedia were more numerous than the females and in the fourth peak, in June 2003, there occurred a conspicuous predominance of $N y$. intermedia females. The highest numbers of both sexes of $N y$. neivai occurred in the two Decembers.

Low Pearson's correlation coefficients, without statistical significance, were obtained for both species between the monthly Williams' geometrical average of both sexes captured in all the ecotopes of the two localities and the monthly rains or minimum average temperature during the 30 days prior to the capture day: JRA smallholding: $N y$. intermedia, rains (n = 33) $(\mathrm{r}=-0.10, \mathrm{p}=0.56)$ and temperature $(\mathrm{r}=0.093 ; \mathrm{p}=$ $0.595) ; N y$. neivai, rains $(\mathrm{r}=-0.07, \mathrm{p}=0.69)$, temperature $(\mathrm{r}$ $=0.091 ; \mathrm{p}=0.595)$ and AG small farm: Ny. intermedia, rains $(\mathrm{n}=24)(\mathrm{r}=-0.08 ; \mathrm{p}=0.73)$, temperature $(\mathrm{r}=0.16 ; \mathrm{p}=0.47)$, Ny. neivai: rains $(\mathrm{r}=0.04 ; \mathrm{p}=0.85)$, temperature $(\mathrm{r}=0.04$; $\mathrm{p}=0.87)$.

A comparison between the geometrical Williams' means of the predominant species, $N y$. intermedia and $N y$. neivai, in the two localities, the JRA smallholding and the GA small farm, during the simultaneous period of capture between March 2002 and December 2003 (20 months), may be seen in table IV. Generally, the means for the ecotopes of the AG small farm for both species were higher (and statistically significant; $p<0.001$ ) than for the corresponding ones on the JRA smallholding, with the exception of $N y$. neivai in the pigsties $(p>0.05)$. As regards the relative numbers of each species among the ecotopes of the same locality, $N y$. intermedia and $N y$. neivai do not show statistically significant differences $(p>0.05)$ in relation to the veranda and hen-house of the JRA smallholding nor does $N y$. neivai as between the pigsty and veranda of the AG small farm $(p>0.05)$.

A total of 762 females captured with automatic light traps, 571 being of $N y$. intermedia, 188 of $N y$. neivai, two of Pi. fischeri and one of $\mathrm{Mg}$. migonei, were dissected to investigate natural infection by flagellates, with negative results.

A total of 863 phlebotomines were captured $(36.3 \%$ males and $63.7 \%$ females) with black and white modified Shannon traps installed simultaneously side by side during the six months from July to December 2002. Of this total, only one female each of Ev. edwardsi and Mg. migonei were captured. Of the remaining phlebotomines, $75.6 \%$ belonged to $N y$. intermedia and $24.4 \%$ to $N y$. neivai. 

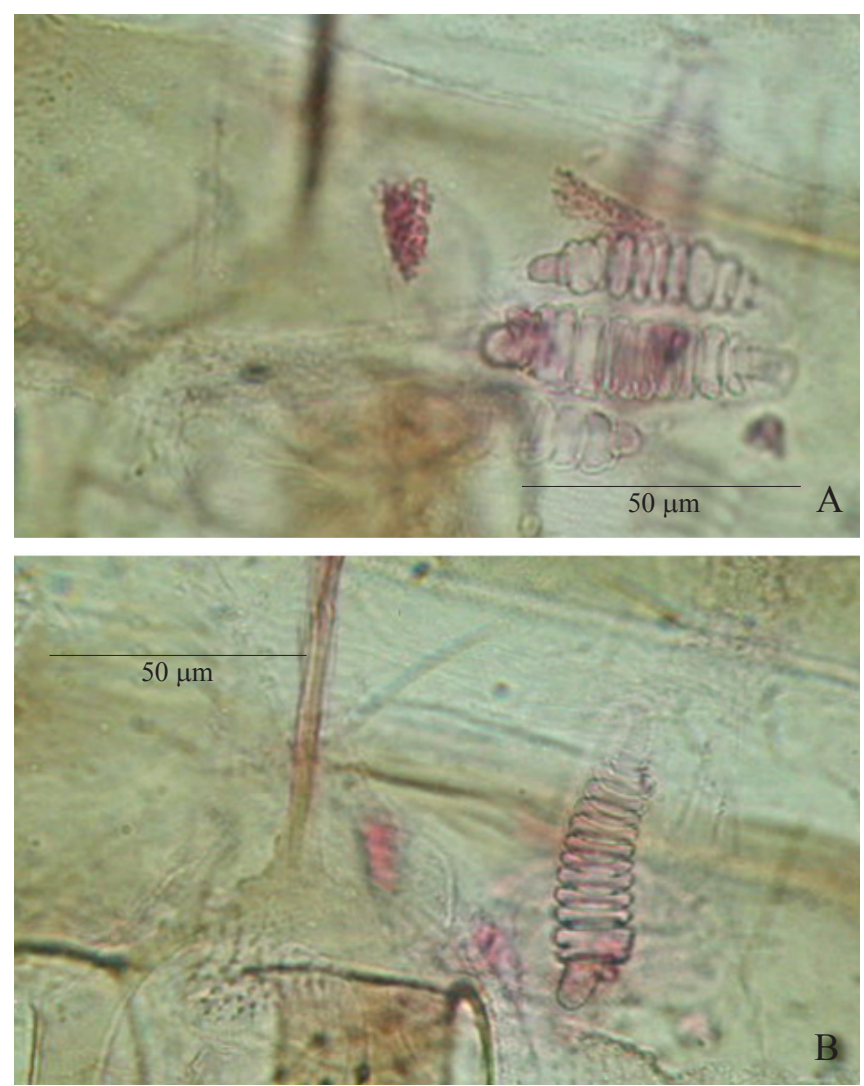

Fig. 3. Hybrid female of $N y$. intermedia and $N y$. neivai. A. At dorsal view, the two external spermathecae belong to $N y$. neivai and that in the middle as well as that in ventral view to $\mathrm{Ny}$. intermedia. B. Spermatheca of $\mathrm{Ny}$. intermedia at ventral view. Ny intermedia presents more robust spermathecae than $N y$. neivai; $N y$. intermedia presents the base of the terminal knob conspicuously wider than the width of the individual sperm duct at the junction with the spermathecae, whereas in Ny. neivai both structures are of the same width. Specimen captured on AG small farm (veranda), Serra district, 27/28-VII2002.

Both males and females were captured predominantly in the white traps but the differences were statistically significant $(\mathrm{p}<0.001)$ only for the females (Table V).

A total of 153 females of $N y$. intermedia and 36 of $N y$. neivai, representing about $1 / 3$ of the total captured, were dissected to investigate for flagellates, with negative results.

\section{DISCUSSION}

The introgression between $N y$. intermedia and $N y$. neivai was suggested by Marcondes et al. (1997) who, using the polymerase chain reaction and direct sequencing of 450 nucleotides of deoxyribonucleic acid (mt DNA), found 10 haplotypes associated with insects presenting a morphology typical of $N y$. intermedia or $N y$. neivai from allopatric areas; however, they found two females from a coastal area of São Paulo state with a morphotype of $N y$. intermedia but with the mtDNA lineage similar to that of $N y$. neivai. Thus, the finding of male and female hybrids in this study, though at low rates $(1.62 / 100,000$ specimens of $N y$. intermedia and 4.1/100,000 specimens of $N y$. neivai), showed that these two species cross naturally, but curiously each one conserves its identity as regards the male and females genital characters, apex of the ejaculatory ducts and spermathecae respectively, as described by Andrade Filho et al. (2003). However, artificial crosses between the two species should be attempted in order to evaluate pre-mating isolation mechanisms and the fitness, fertility and morphological characteristics of the F1 offspring.

Since the first reported human cases of cutaneous leishmaniasis in the Ribeira Valley region, the disease has been associated with environments having modified native or degraded vegetation. This man-made devastation affects the fauna, some of its species being eliminated or having their density greatly reduced, while others gifted with greater adaptability may benefit, as occurred with $\mathrm{Ny}$. intermedia $\mathrm{s}$. lat. (Gomes et al. 1986). It is opportune to remember that this taxon in this region includes two sympatric species: Ny. intermedia s. str. and Ny. neivai (Marcondes 1996; Marcondes et al. 1998), both implicated as vectors of cutaneous leishmaniasis (Andrade Filho et al. 2007). The above mentioned aspects can be clearly seen in a comparison between the captures made in the Serra district, the area in
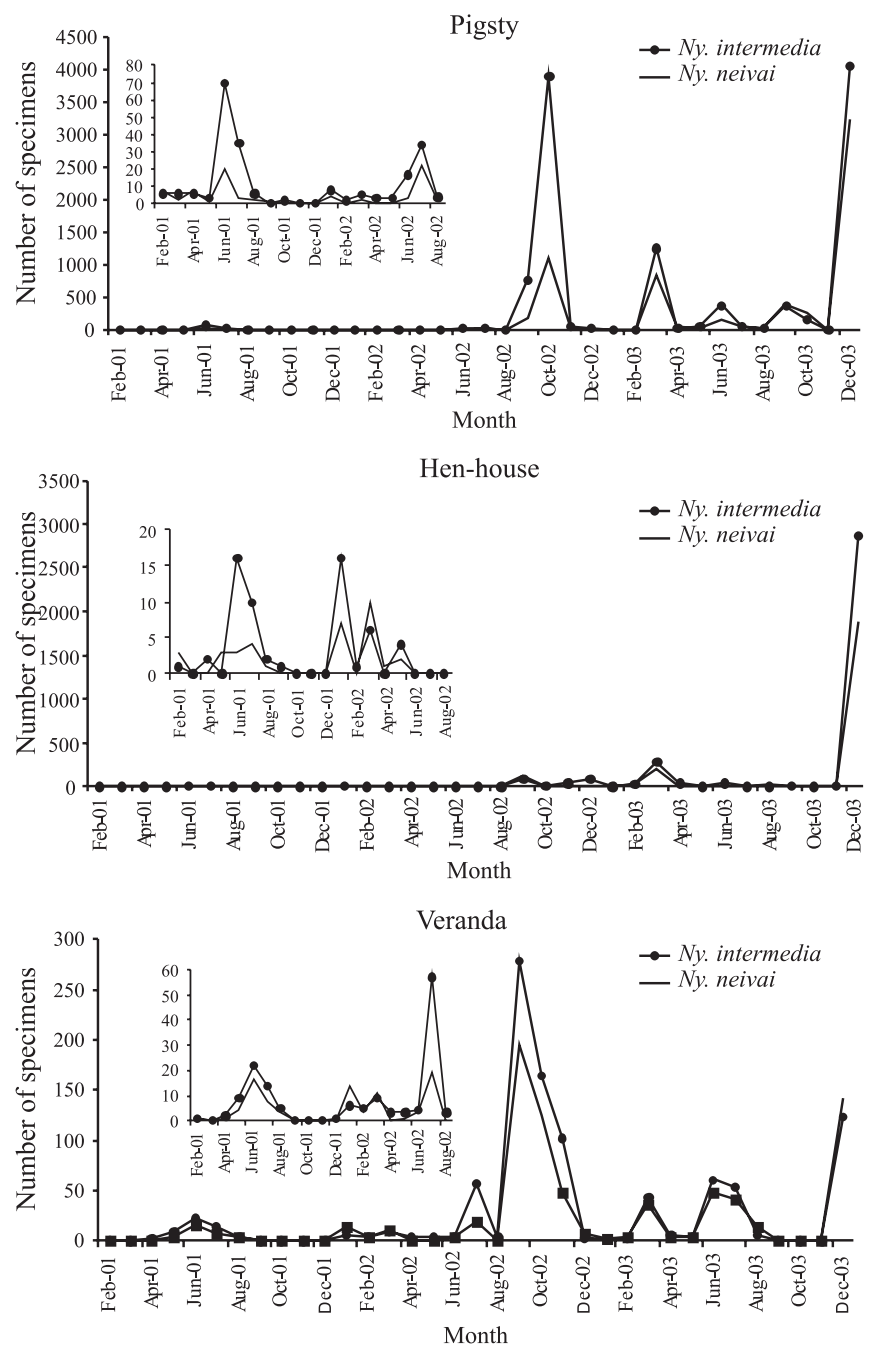

Fig. 4. Monthly distribution of both sexes of $N y$. intermedia and $N y$. neivai in the three ecotopes on JRA smallholding, from February 2001 to December 2003. 
Table III. Numbers of phlebotomines captured on the JRA smallholding and AG small farm, Serra district, Iporanga municipality, with automatic light traps, by species and ecotope, between February 2001 and December 2003, and arithmetical mean and Williams'geometrical mean, by capture, Shannon diversity (H) and Pielou's evenness (J) indices by ecotope.

\begin{tabular}{|c|c|c|c|c|c|c|c|c|c|c|c|c|c|c|}
\hline \multirow{3}{*}{$\begin{array}{l}\text { Site } \\
\text { Ecotope } \\
\text { Number of captures } \\
\text { Snecies sex }\end{array}$} & \multicolumn{6}{|c|}{ JRA smallholding } & & & \multicolumn{2}{|c|}{$\begin{array}{l}\text { AG small farm } \\
\text { hen-house }\end{array}$} & \multicolumn{2}{|c|}{ pigsty } & \multicolumn{2}{|c|}{ Total } \\
\hline & & & \multicolumn{2}{|c|}{ 11611-10use } & \multicolumn{2}{|c|}{ Prgory } & \multicolumn{2}{|c|}{22} & \multicolumn{2}{|c|}{23} & \multicolumn{2}{|c|}{23} & \multicolumn{2}{|c|}{173} \\
\hline & MF & $\%$ & MF & $\%$ & MF & $\%$ & MF & $\%$ & MF & $\%$ & MF & $\%$ & MF & $\%$ \\
\hline Br. carvalheiroi & - & - & - & - & 1 & 0.005 & 2 & 0.02 & - & - & 1 & 0.01 & 4 & 0.005 \\
\hline Br. cunhai & 2 & 0.11 & 1 & 0.02 & - & & 34 & 0.32 & 16 & 0,044 & 3 & 0.02 & 56 & 0.064 \\
\hline Br. nitzulescui & 3 & 0.16 & 1 & 0.02 & 1 & 0.005 & - & - & 4 & 0,011 & - & - & 9 & 0.010 \\
\hline Ev. edwardsi & 2 & 0.11 & - & - & - & - & 2 & 0.02 & 2 & 0,006 & 2 & 0.01 & 8 & 0.009 \\
\hline Ex. firmatoi & 1 & 0.06 & - & - & 3 & 0.02 & - & - & 7 & 0,019 & 8 & 0.06 & 19 & 0.022 \\
\hline Lu. longipalpis & - & - & - & - & 2 & 0.02 & - & - & - & - & - & - & 2 & 0.002 \\
\hline Mg. $m$ & 10 & 0.56 & 72 & 1.18 & 133 & 0.73 & 11 & 0.1 & 497 & 1.371 & 177 & 1.23 & 900 & 1.032 \\
\hline Mg. $r$ & - & - & - & - & - & - & - & - & 9 & 0.0 & - & - & 9 & 0.010 \\
\hline Mg. vaniae & - & - & - & - & - & - & 1 & 0.01 & 6 & 0.017 & - & - & 7 & 0.008 \\
\hline Mi.pe & - & - & - & - & - & - & 2 & $0 .($ & 2 & 0.0 & 3 & 0.02 & 7 & 0.008 \\
\hline media & 992 & 55.61 & 3554 & 58.42 & 11326 & 62.76 & 8185 & 77.2 & 26702 & 73.640 & 10419 & 72.11 & 61178 & 70.139 \\
\hline Ny. neivai & 759 & 42.54 & 2352 & 38.67 & 6401 & 35.47 & 2336 & 22.03 & 8787 & 24.233 & 3574 & 24.74 & 24209 & 27.755 \\
\hline Pa. lanei & - & - & 4 & 0.06 & 4 & 0.02 & - & - & 4 & 0.011 & 3 & 0.02 & 15 & 0.017 \\
\hline Pa.pascalei & 6 & 0.34 & 1 & 0.02 & - & - & 3 & 0.03 & 11 & 0.030 & 1 & 0.0 & 22 & 0.025 \\
\hline$P a$. sp. & - & - & - & - & 4 & 0.02 & - & - & 2 & 0.006 & 1 & 0.01 & 7 & 0.008 \\
\hline Pi. fischeri & 7 & 0.39 & 98 & 1.61 & 170 & 0.94 & 21 & 0.2 & 192 & 0.530 & 250 & 1.73 & 738 & 0.846 \\
\hline Pi. monticola & - & - & - & - & - & 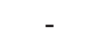 & - & - & 2 & 0.0 & 2 & & 4 & 0.005 \\
\hline Ps. ayl & 1 & 0.06 & - & - & 1 & 0.005 & 4 & 0.04 & 9 & 0.0 & 2 & 0.01 & 17 & 0.020 \\
\hline Ps. geniculatus & 1 & 0.06 & - & - & 1 & 0.005 & 1 & 0.01 & 8 & 0.022 & 2 & 0.01 & 13 & 0.015 \\
\hline Total & 1,784 & 100 & 6,083 & 100 & 18,047 & 100 & 10602 & 100 & 36260 & 99.244 & 14448 & 100.00 & 87224 & 100.00 \\
\hline Arithme & 50.97 & & 173.8 & & 515.6 & & 481.91 & & & & 628.17 & & 504.18 & \\
\hline Williar & 9.56 & & 8.82 & & 30.16 & & 151.32 & & 666.93 & & 178.04 & & 46.54 & \\
\hline $\mathrm{H}$ & 0.772 & & 0.810 & & 0.749 & & 0.583 & & 0.675 & & 0.722 & & 0.711 & \\
\hline J & 0.322 & & 0.390 & & 0.301 & & 0.235 & & 0.229 & & 0.266 & & 0.242 & \\
\hline
\end{tabular}

which the lodgings for visitors to the PETAR are situated, and those made within this latter park, particularly at the Santana nucleus (Galati et al. 2010b). Thus, though both areas have very similar phlebotomine fauna, differing by only a few species, they present completely different situations in relation to the frequency of the leishmaniasis vectors, $N y$. intermedia and $N y$. neivai. In this park, the highest mean of these species (insects/trap) occurred at the site where they were most numerous (the open camp site) 2.91 and 0.43 , respectively, while in the Serra district these values for the JRA smallholding and AG small farm, respectively, were, for $N y$. intermedia from 28.34 to 1160.96 and for $N y$. neivai from 21.69 to 382.04 . The abundances of the species in the two areas were also clearly different. In the Serra district the Standardized Index of Species Abundance of $N y$. intermedia showed the latter's absolute predominance (SISA $=1.0$ ), followed by $\mathrm{Ny}$. neivai (0.935), Pi. fischeri (0.839) and $\mathrm{Mg}$. migonei (0.817), and in the PETAR the four most abundant species were $P$ a. pascalei (SISA $=0.922)$, Ps. ayrozai $(0.848)$, $P a$. lanei (0.795) and Ps. geniculatus (0.727). These latter four are better adapted to forested environments (Gomes \& Galati. 1989; Marcondes et al. 2001), differently from those species that predominated in the Serra district, better adapted to anthropic environments or the forest edge (Gomes et al. 1980, 1983; Souza et al. 2001).

Considering that in the PETAR, Ny. intermedia was four times more frequent than $N y$. neivai (Galati et al. 2010b) and on the JRA smallholding, $N y$. intermedia presented a Williams' mean on the veranda and in the hen-house slightly higher than that for $N y$. neivai (1.19 and 1.33, respectively), and in the pigsty, $N y$. intermedia was 1.9 times more numerous than $N y$. neivai, while on the AG small farm these values were $2.57,3.47$ and 4.41 times, respectively, it may be deduced that $N y$. neivai is adapting better to modified, open areas than is $N y$. intermedia. On the other hand, the higher frequencies of $N y$. intermedia in the three ecotopes of the AG small farm than on the JRA smallholding (Table IV) may be attributed to the greater proximity of the ecotopes to the forest in the former locality and also possibly to the fact that the JRA smallholding has been established in the area longer than has the AG small farm. The allopatric occurrence of $N y$. intermedia on the Atlantic coast of the São Paulo state, with its more humid climate, and of $N y$. neivai on the drier inland plateau, also reinforces this point of view. Thus, perhaps $N y$. neivai is also the predominant species in other areas of the Ribeira Valley, the deforestation of which occurred over a considerable period many years ago.

The capture of a greater number of specimens of $N y$. intermedia than of $N y$. neivai in the pigsty than in the two other ecotopes in the respective areas, seems to indicate the greater attractiveness of that ecotope to the former species. The greater predominance of $N y$. intermedia than of $N y$. neivai in the hen-house on the AG small farm can be due in part to the period sampled (the last six months of the year), and in part to 
the construction of stalls to house sows and their litters beside the hen-house, so that the traps in this latter ecotope during this period were benefited by the attractiveness of two kinds of animal, whereas those in the pigsty, installed at the same site throughout the study, had only the pigs as attraction.

The monthly distributions of $N y$. intermedia and $N y$. neivai showed peaks in different months in distinct ecotopes, though on the other hand no significant correlation was observed between the frequencies of these species and the rains and temperatures over the period of 30 days before each capture. So these species may be active during any period, some times at high frequencies. As they are the main vectors of cutaneous leishmaniasis the risk of the transmission of this disease exists throughout the year, as observed by Gomes et al. (1982) and Domingos et al. (1998).

On the AG small farm the higher predominance of $N y$. intermedia than of $N y$. neivai in the automatic light traps was maintained in the captures made with black or white modified Shannon traps. In the captures undertaken throughout the nocturnal period on the JRA smallholding (Galati et al. 2010c), Ny. neivai predominated over $N y$. intermedia, but without any statistical significance. The greater attractiveness of the white traps as compared with the black ones, on the AG small farm was also observed on the JRA smallholding, but in this latter area the black traps attracted proportionally more females of $N y$. intermedia than of $N y$. neivai, while on the AG smallholding the proportion was closely similar. These differences can be due to the short period of capture both as regards the months and the times concerned.

The negative results for flagellates found in the dissection of the sandflies may perhaps be due to the fact that our collections were made in a period of low level circulation of the agent of leishmaniasis, since it is normal, in endemic areas of the São Paulo state, for periods of transmission to alternate with silent ones. Of the 63 cases reported in the period 2000$2006,10,2,4$ and 20 of them occurred, respectively, in the four years from 2001 to 2004 (CVE 2007), revealing a coincidence between the larger numbers of dissected females and the low frequencies of the numbers of cases.

Pi. fischeri and Mg. migonei, the third and fourth most abundant species, are frequently found in association with $N y$. intermedia s. lat. in some areas of the Ribeira Valley. Sometimes Pi. fischeri is predominant over $\mathrm{Mg}$. migonei
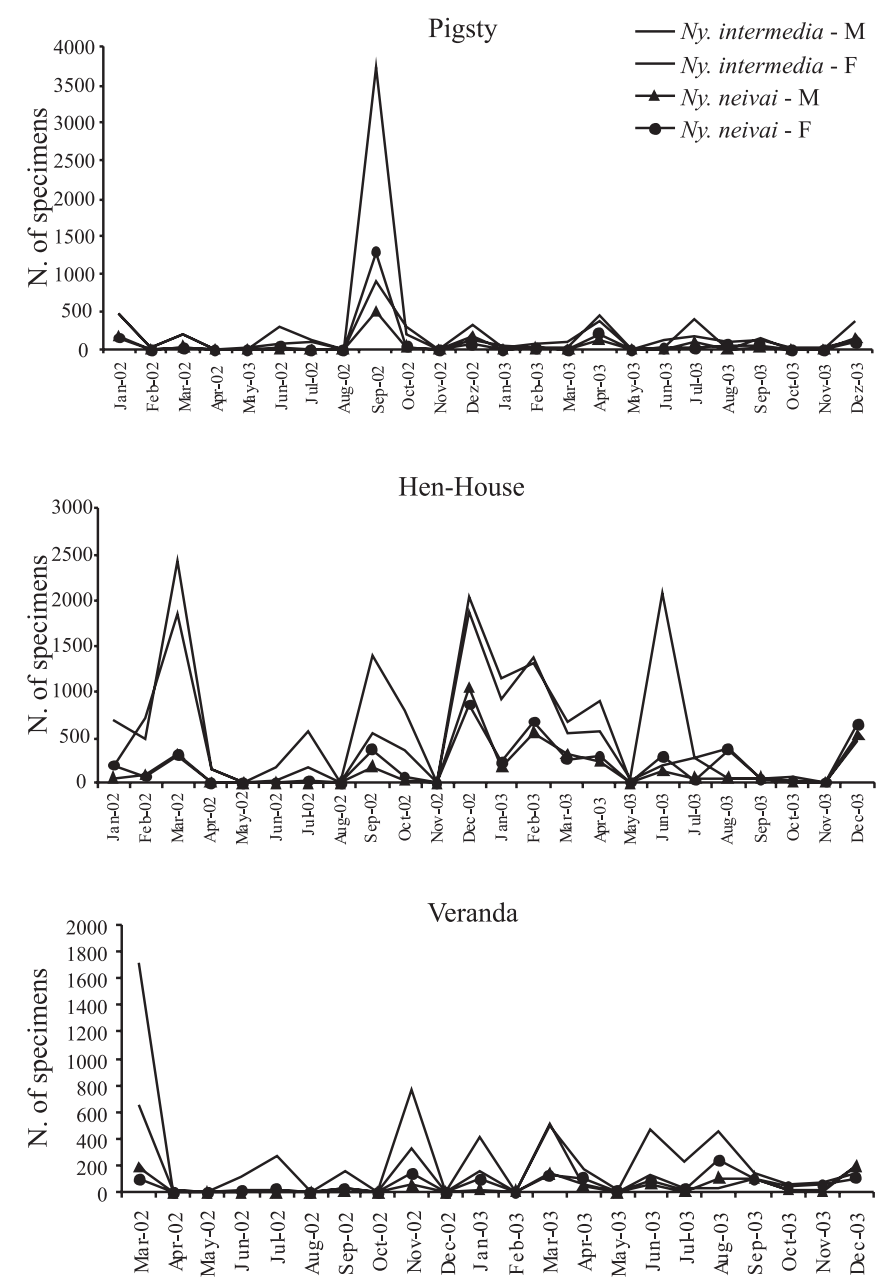

Fig. 5. Monthly distribution of Ny. intermedia and Ny. neivai, by sex, in the three ecotopes on AG small farm, between January 2002 and December 2003.

(Gomes et al. 1980, 1990; Gomes \& Galati 1989; Taniguchi et al. 2002) at others the reverse is true (Forattini et al. 1976; Gomes \& Galati 1987, Gomes et al. 1986; Domingos et al. 1998).

The higher species richness observed on the AG small farm than on the JRA smallholding is certainly due to the proximity of the former area to the forest, where probably Pi. monticola,

Table IV. Numbers and Williams' means of the predominant species, Ny. intermedia and Ny. neivai, on the JRA smallholding and GA small farm, during the common period of capture (20 months) between March 2002 and December 2003.

\begin{tabular}{|c|c|c|c|c|c|c|c|c|}
\hline \multirow[t]{2}{*}{ Ecotope } & \multicolumn{3}{|c|}{ Ny.intermedia } & \multicolumn{3}{|c|}{ Ny.neivai } & \multicolumn{2}{|c|}{ Total } \\
\hline & Number & $\%$ & Williams' mean & Number & $\%$ & Williams' mean & Number & $\%$ \\
\hline JRA - veranda & 920 & 56.6 & $11.56^{\mathrm{a}}$ & 705 & 43.4 & $9.67^{\mathrm{b}}$ & 1,625 & 100.0 \\
\hline JRA - henhouse & 3,502 & 60.0 & $11.37^{\mathrm{c}}$ & 2,326 & 40.0 & $8.50^{\mathrm{d}}$ & 5,828 & 100.0 \\
\hline JRA - pigsty & 11,131 & 63.7 & $55.68^{\mathrm{e}}$ & 6,338 & 36.3 & $29.17^{\mathrm{f}}$ & 17,469 & 100.0 \\
\hline$A G$ - veranda & 8,065 & 77.7 & $114.7^{\mathrm{g}}$ & 2,309 & 22.3 & $44.58^{\mathrm{h}}$ & 10,374 & 100.0 \\
\hline AG - henhouse & 24,231 & 74.4 & $402.64^{\mathrm{i}}$ & 8,323 & 25.6 & $116.18^{j}$ & 32,554 & 100.0 \\
\hline AG - pigsty & 9,417 & 74.4 & $147.86^{\mathrm{k}}$ & 3,246 & 25.6 & $33.50^{1}$ & 12,663 & 100.0 \\
\hline Total & 57,266 & 71.1 & - & 23,247 & 28.9 & - & 80,513 & 100.0 \\
\hline
\end{tabular}

$\chi^{2}$ test: for all the comparisons made, except those between: a x b; $\mathrm{c} \mathrm{x} \mathrm{d;} \mathrm{a} \mathrm{x} \mathrm{c;} \mathrm{b} \mathrm{x} \mathrm{d,} \mathrm{fx} \mathrm{land} \mathrm{h} \mathrm{x} 1(\mathrm{p}>0.05$; d.f. $=1)$, between the same species in distinct ecotopes or vice-versa, the differences being statistically significant $(\mathrm{p}<0.01 ;$ d.f $=1)$. 
Table V. Numbers of phlebotomines, by species and sex, captured on the black or white Shannon traps, females dissected (between parentheses) and values of the $\chi^{2}$ test comparing both traps. The AG small farm, Serra district, July to December 2002.

\begin{tabular}{|c|c|c|c|c|c|c|c|c|}
\hline \multirow{2}{*}{$\begin{array}{l}\text { Trap } \\
\text { Species sex }\end{array}$} & \multicolumn{2}{|c|}{ Black (B) } & \multicolumn{2}{|c|}{ White (W) } & \multicolumn{2}{|c|}{ Total } & \multirow{2}{*}{$\begin{array}{c}\chi^{2} B \times W \\
M\end{array}$} & \multirow{2}{*}{$\begin{array}{c}\chi^{2} \mathrm{~B} \times \mathrm{W} \\
\mathrm{F}\end{array}$} \\
\hline & M & F & $\mathrm{M}$ & $\mathrm{F}$ & M & $\mathrm{F}$ & & \\
\hline Ev. edwardsi & - & - & - & 1 & - & 1 & - & - \\
\hline Mg. migonei & - & 1 & - & - & - & 1 & - & - \\
\hline Ny. intermedia & 111 & $80(25)$ & 93 & $367(128)$ & 204 & $447(153)$ & $1.59^{\mathrm{n}}$ & $184.27^{1}$ \\
\hline Ny. neivai & 46 & $19(5)$ & 63 & $82(31)$ & 109 & $101(36)$ & $2.65^{\mathrm{n}}$ & $39.30^{1}$ \\
\hline Total & 157 & $100(30)$ & 156 & $450(159)$ & 313 & $550(189)$ & $0.003^{\mathrm{n}}$ & $222.73^{1}$ \\
\hline
\end{tabular}

$\mathrm{n}=$ not significant $(\mathrm{p}>0.05 ;$ d.f. $=1) ; 1(\mathrm{p}<0.00 ;$ d.f. $=1)$.

$M g$. rabelloi and $M g$. vaniae have their breeding places. This last species is known still to inhabit this locality (Galati et al. 2007). On the other hand, Lu. longipalpis was captured only on the JRA smallholding. The finding of this latter species, the main vector of the American visceral leishmaniasis agent, in this peridomicile is noteworthy as it has been a long time since this area first began to undergo modification, indicating the capacity of this sandfly population to adapt to human environments as has happened in other areas, including urban ones (Lainson \& Rangel 2005). Entomological surveillance for the control of visceral leishmaniasis in this area has, therefore, become imperative.

Acknowledgements. Our thanks to the guide, Mr. Jânio Ribeiro de Andrade and his family, and to Mr. Antônio Gurgel, owners of the two properties researched, for permitting us to make the captures, as also to Dr. Ademir Galati who provided the necessary logistic support. Thanks are also due to Mr. Arthur Anthony Boorne for his correction of the English text. Financial support: FAPESP (00/06811-0) and IBAMA-SP licence (process n. $02027007000 / 2000-76$ )

\section{REFERENCES}

Aguiar, G. M. \& W. M. Medeiros. 2003. Distribuição regional e hábitats das espécies de flebotomíneos do Brasil, p. 207-255. In: E. F. Rangel \& R. Lainson (orgs.). Flebotomíneos do Brasil. Rio de Janeiro, Fiocruz, $367 \mathrm{p}$.

Alexander, B. 1987. Dispersal of phlebotomine sand flies (Diptera: Psychodidae) in a Colombian coffee plantation. Journal of Medical Entomology 24: 552-558.

Alves, V. R. 2007. Artrópodes cavernícolas com ênfase em flebotomíneos (Diptera: Psychodidae) do município de Presidente Figueiredo, Amazonas, Brasil. Dissertação de Mestrado - INPA/UFAM, Manaus. http:/tede.inpa.gov.br/tde_arquivos/5/TDE-2009-01-08T150757Z-124/ Publico/Dissertacao_Veracilda.pdf

Alves, V. R.; R. A. Freitas \& T. Barret. 2008. Lutzomyia maruaga (Diptera: Psychodidae), a new bat-cave sand fly from Amazonas, Brazil. Memórias do Instituto Oswaldo Cruz 103: 251-253.

Andrade Filho, J. D.; A. C. L. Silva \& A. L. Falcão. 2001. Phlebotomine sandflies in the State of Piauí, Brazil (Diptera: Psychodidae: Phlebotominae). Memórias do Instituto Oswaldo Cruz 96: 10851087.

Andrade Filho, J. D.; E. A. B. Galati \& A. L. Falcão. 2003. Redescription of Nyssomyia intermedia (Lutz \& Neiva, 1912) and Nyssomyia neivai (Pinto, 1926) (Diptera: Psychodidae). Memórias do Instituto Oswaldo Cruz 98: $1059-1065$.

Andrade Filho, J. D.; E. A. B. Galati \& A. L. Falcão. 2007. Nyssomyia intermedia (Lutz \& Neiva, 1912) and Nyssomyia neivai (Pinto, 1926) (Diptera: Psychodidae: Phlebotominae) geographical distribution and epidemiological importance. Memórias do Instituto Oswaldo Cruz 102: 481-487.

Auler, A. S. 2002. Karst areas in Brazil and the potential for major caves - an overview. Boletín de la Sociedad Venezolana de Espeleología 36: $29-35$.

Camargo, L. B. \& H. Langoni. 2006. Impact of leishmaniasis on public health. Journal of Venomous Animals and Toxins including Tropical Diseases 12: 527-548.

Casanova, C.; A. I. P. Costa \& D. Natal. 2005. Dispersal pattern of the sand fly Lutzomyia neivai (Diptera: Psychodidae) in a cutaneous leishmaniasis endemic rural area in Southeastern Brazil. Memórias do Instituto Oswaldo Cruz 100: 717-724.

Centro de Vigilância Epidemiológica Alexandre Vranjac, Secretaria de Estado da Saúde de São Paulo (CVE). 2007. Leishmaniose Tegumentar Americana < http://www.cve.saude.sp.gov.br/htm/zoo/lta_reg.htm> $(10 / 09 / 2007)$.

CIIAGRO (Centro Integrado de Informações Agrometeorológicas). 2007. Resenha Agrometeorológica. Boletim Mensal < http://www.ciiagro.sp. gov.> (accessed 5 September 2007).

Dejeux, P. 2004. Leishmaniasis: current situation and new perspectives. Comparative Immunology, Microbiology \& Infectious Diseases 27: 305-318.

Domingos, M. F.; G. C. Carreri-Bruno; R. M. C. Ciaravolo; E. A. B. Galati; D. M. V. Wanderley \& F. M. A. Corrêa. 1998. Leishmaniose tegumentar americana: flebotomíneos de área de transmissão, no município de Pedro de Toledo, região sul do Estado de São Paulo. Revista da Sociedade Brasileira de Medicina Tropical 31: 425-432.

Forattini, O. P. 1973. Entomologia Médica. Phlebotominae. Leishmanioses. Bartonelose. São Paulo, Ed. Edgard Blücher Ltda, 658 p.

Forattini, O. P.; E. X. Rabello; O. P. Serra; M. D. Cotrim; E. A. B. Galati \& J. M. S. Barata. 1976. Observações sobre a transmissão da leishmaniose tegumentar no Estado de São Paulo, Brasil. Revista de Saúde Pública 10: $31-43$.

Galati, E. A. B. 2003a. Classificação de Phlebotominae, 23-51. In: E. F. Rangel \& R. Lainson (orgs.). Flebotomíneos do Brasil. Rio de Janeiro, Fiocruz, $367 \mathrm{p}$.

Galati, E. A. B. 2003b. Morfologia, terminologia de adultos e identificação dos táxons da América, 53-175. In: E. F. Rangel \& R. Lainson (orgs.). Flebotomíneos do Brasil. Rio de Janeiro, Fiocruz, 367 p.

Galati, E. A. B.; V. L. B. Nunes; F. A. Rego-Jr; E. T. Oshiro \& M. Rodrigues. 1997. Estudo de flebotomíneos (Diptera, Psychodidae) em foco de leishmaniose visceral no Estado de Mato Grosso do Sul, Brasil. Revista de Saúde Pública 31: 378-90.

Galati, E. A. B.; V. L. B. Nunes; M. E. C. Dorval; G. Cristaldo; H. C. Rocha; R. M. Gonçalves-Andrade \& G. Naufel. 2001. Attractiveness of black Shannon trap for phlebotomines. Memórias do Instituto Oswaldo Cruz 96: 641-647.

Galati, E. A. B.; V. L. B. Nunes; P. C. Boggiani; M. E. C. Dorval; G. Cristaldo; H. C. Rocha; E. T. Oshiro; R. M. Gonçalves-Andrade \& G. Naufel. 2003a. Phlebotomine (Diptera, Psychodidae) in caves of the Serra da Bodoquena, Mato Grosso do Sul state, Brazil. Revista Brasileira de Entomologia 47: 283-296.

Galati, E. A. B.; A. M. Marassá \& R. M. Gonçalves-Andrade. 2003b. Micropygomyia (Sauromyia) petari, a new species of Phlebotominae (Diptera, Psychodidae) from Vale do Ribeira, São Paulo State, Brazil. Revista Brasileira de Entomologia 47: 455-459.

Galati, E. A. B.; V. L. B. Nunes; P. C. Boggiani; M. E. C. Dorval; G. Cristaldo; H. C. Rocha; E. T. Oshiro \& G. A. Damasceno-Júnior. 2006. Phlebotomine (Diptera, Psychodidae) in forested areas of the Serra da 
Bodoquena, Mato Grosso do Sul State, Brazil. Memórias do Instituto Oswaldo Cruz 101: 175-193.

Galati, E. A. B.; M. B. Fonseca \& A. M. Marassá. 2007. Review of the subgenus Migonemyia (Migonemyia) Galati 1995, with description of a new species Migonemyia vaniae. Memórias do Instituto Oswaldo Cruz 102: 605-615.

Galati, E. A. B.; A. M. Marassá; M. B. Fonseca \& E. M. F. Bueno. 2009. Dispersal and survival of Nyssomyia intermedia and Nyssomyia neivai (Diptera: Psychodidae: Phlebotominae) in a cutaneous leishmaniasis endemic area of the speleological province of the Ribeira Valley, state of São Paulo, Brazil. Memórias do Instituto Oswaldo Cruz 104: 11481158.

Galati, E. A. B.; A. M. Marassá; R. M. Gonçalves-Andrade; C. A. Consales \& E. M. F. Bueno. 2010a. Phlebotomines (Diptera, Psychodidae) in the Ribeira Valley Speleological Province - 1. Parque Estadual Intervales, State of São Paulo, Brazil. Revista Brasileira de Entomologia 54: 311-321.

Galati, E. A. B.; A. M. Marassá; R. M. Gonçalves-Andrade; C. A. Consales \& E. M. F. Bueno. 2010b. Phlebotomines (Diptera, Psychodidae) in the Speleological Province of the Ribeira Valley: 2. Parque Estadual do Alto Ribeira (PETAR), São Paulo State, Brazil. Revista Brasileira de Entomologia 54: 477-487.

Galati, E. A. B.; A. M. Marassá; R. M. Gonçalves-Andrade; E. M. F. Bueno; B. R. Paiva \& Malafronte R. S. 2010c. Nyssomyia intermedia (Lutz \& Neiva) and Ny. neivai (Pinto) (Diptera, Psychodidae, Phlebotominae) in a sympatric area: seasonal and nocturnal hourly rhythm of the species in captures made on the black and white modified Shannon traps. Revista Brasileira de Entomologia 54: 677-686.

Giatti, L. L.; A. A. Rocha; F. A. Santos; S. C. Bitencourt \& S. R. M. Pieroni. 2004. Condições de saneamento básico em Iporanga, Estado de São Paulo. Revista de Saúde Pública 38: 571-577.

Gomes, A. C. \& E. A. B. Galati. 1987. Aspectos ecológicos da leishmaniose tegumentar americana. 5. Estratificação da atividade espacial e estacional de Phlebotominae (Diptera, Psychodidae) em áreas de cultura agrícola da região do Vale do Ribeira, Estado de São Paulo, Brasil. Memórias do Instituto Oswaldo Cruz 82: 467-473.

Gomes, A. C. \& E. A. B. Galati. 1989. Aspectos ecológicos da leishmaniose tegumentar americana. 7. Capacidade vetorial flebotomínea em ambiente florestal primário do Sistema da Serra do Mar, região do Vale do Ribeira, Estado de São Paulo. Revista de Saúde Pública 23: 136-142.

Gomes, A. C.; E. X. Rabello; J. L. Santos \& E. A. B. Galati. 1980. Aspectos ecológicos da leishmaniose tegumentar americana. I. Estudo experimental da freqüência de flebotomíneos a ecótopos artificiais com referência especial a Psychodopygus intermedius. Revista de Saúde Pública 14: 540-556.

Gomes, A. C.; E. X. Rabello; J. L. Santos \& E. A. B. Galati. 1982. Aspectos ecológicos da leishmaniose tegumentar americana. 2. Ecótopo artificial como abrigo de Psychodopygus intermedius e observações sobre a alimentação e reprodução sob influência de fatores físicos naturais. Revista de Saúde Pública 16: 149-159.

Gomes, A. C.; E. X. Rabello; J. L. Santos \& E. A. B. Galati. 1983. Aspectos ecológicos da leishmaniose tegumentar americana. 3. Observações naturais sobre o ritmo diário da atividade de Psychodopygus intermedius em ambiente extraforestal. Revista de Saúde Pública 17: 23-30.

Gomes, A. C.; J. L. Santos \& E. A. B. Galati. 1986. Ecological aspects of American cutaneous leishmaniasis 4. Observations on the endophilic behavior of the sandfly and the vectorial role of Psychodopygus intermedius in the Ribeira valley region of the São Paulo state. Revista de Saúde Pública 20: 280-287.

Gomes, A. C.; J. M. S. Barata; E. O. Rocha e Silva \& E. A. B. Galati. 1989. Aspectos ecológicos da leishmaniose tegumentar americana. 6. Fauna flebotomínica antropófila de matas residuais situadas na região centronordeste do Estado de São Paulo, Brasil. Revista do Instituto de Medicina Tropical de São Paulo 31: 32-39.

Gomes, A. C.; S. G. Coutinho; G. V. Paim; S. M. O. Oliveira; E. A. B. Galati; M. P. Nunes; N. A. Capinzaiki; Y. I. Yamamoto \& P. Rotter. 1990. Aspectos ecológicos da leishmaniose tegumentar americana. 8. Avaliação da atividade enzoótica de Leishmania (Viannia) braziliensis, em ambiente florestal e peridomiciliar, Região do Vale do Ribeira, Estado de São Paulo, Brasil. Revista do Instituto de Medicina Tropical de São Paulo 32: 105-115.

Haddow, A. J. 1960. Studies on the biting-habits and medical importance of
East African mosquitos in the genus Aedes. I. Subgenera Aedimorphus, Banksinella and Nunnius. Bulletin of Entomological Research 50: 759-779.

Hayek, L. A. C. \& M. A. Buzas. 1997. Surveying Natural Populations. New York, Columbia University Press, 563 p.

Karmann, I. \& J. A. Ferrari. 2002. Carste e Cavernas do Parque Estadual Turístico do Alto Ribeira (PETAR), SP - Sistemas de cavernas com paisagens subterrâneas únicas, p. 401-413. In: Schobbenhaus, C.; D. A. Campos; E. T. Queiroz; M. Winge \& M. L. C. Berbert-Born (edits.) Sítios Geológicos e Paleontológicos do Brasil. 1. ed. Brasília: DNPM/ CPRM - Comissão Brasileira de Sítios Geológicos e Paleobiológicos (SIGEP), v. 01, $554 \mathrm{p}$.

Lainson, R. \& E. F. Rangel. 2005. Lutzomyia longipalpis and the ecoepidemiology of American visceral leishmaniasis, with particular reference to Brazil - A review. Memórias do Instituto Oswaldo Cruz 100: $811-827$.

Lainson, R. \& J. J. Shaw. 2005. New World leishmaniasis, 313-349. In: F. E. G. Cox; J. P. Kreier \& D. Wakelin (eds.). Topley \& Wilson's Microbiology and Microbial Infections, Parasitology. $10^{\text {th }}$ ed. London, Arnold, 883 p.

Marcondes, C. B. 1996. A redescription of Lutzomyia (Nyssomyia) intermedia (Lutz \& Neiva, 1912), and resurrection of L. neivai (Pinto, 1926) (Diptera, Psychodidae, Phlebotominae). Memórias do Instituto Oswaldo Cruz 91: 457-462.

Marcondes, C. B. 2007. A proposal of generic and subgeneric abbreviations for phlebotomine sandflies (Diptera: Psychodidae: Phlebotominae) of the world. Entomological News 118: 351-356.

Marcondes, C. B.; J. C. Day \& P. D. Ready. 1997. Introgression between Lutzomyia intermedia and both Lu. neivai and Lu. whitmani, and their roles as vectors of Leishmania braziliensis. Transactions of the Royal Society of Tropical Medicine and Hygiene 91: 725-726.

Marcondes, C. B.; A. L. Lozovei \& J. H. Vilela. 1998. Distribuição geográfica de flebotomíneos do complexo Lutzomyia intermedia (Lutz \& Neiva, 1912) (Diptera, Psychodidae). Revista da Sociedade Brasileira de Medicina Tropical 31: 51-58.

Marcondes, C. B.; L. G. Santos-Neto \& A. L. Lozovei. 2001. Ecology of phlebotomine sandflies in Brazilian Atlantic forest. Revista da Sociedade Brasileira de Medicina Tropical 34: 255-260.

Morrison, A. C.; C. Ferro; R. Tesh. 1993a. Host preference of sand fly Lutzomyia longipalpis at an endemic focus of American visceral leishmaniasis in Colombia. American Journal of Tropical Medicine and Hygiene 49: 68-75.

Morrison, A. C.; C. Ferro; A. Morales; R. B. Tesh \& M. C. Wilson. 1993b. Dispersal of the sandfly Lutzomyia longipalpis (Diptera: Psychodidae) at an endemic focus of visceral leishmaniasis in Colombia. Journal of Medical Entomology 30: 427-435.

Natal, D.; D. Marucci; I. M. Reis \& E. A. B. Galati. 1991. Modificação da armadilha CDC com testes para coletas de flebotomíneos (Diptera). Revista Brasileira de Entomologia 35: 697-700.

Nimer, E. 1977. Geografia do Brasil - Região Sudeste. Rio de Janeiro, IBGE, $667 \mathrm{p}$.

Pita-Pereira, D.; M. A. Cardoso; C. R. Alves; R. P. Brazil \& C. Britto. 2008. Detection of natural infection in Lutzomyia cruzi and Lutzomyia forattinii (Diptera: Psychodidae: Phlebotominae) by Leishmania infantum chagasi in an endemic area of visceral leishmaniasis in Brazil using a PCR multiplex assay. Acta Tropica 107: 66-69.

Rangel, E. F. \& R. Lainson. 2003. Transmissores de leishmaniose tegumentar americana, 291-309. In: E. F. Rangel \& R. Lainson (orgs.). Flebotomíneos do Brasil, Rio de Janeiro, Fiocruz, 367 p.

Roberts, D. R. \& B. P. Hsi. 1979. An index of species abundance for use with mosquito surveillance data. Environmental Entomology 8: 1007-13.

Santos, S. O.; J. Arias; A. A. Ribeiro; M. P. Hoffmann. R. A. Freitas \& M. A. F. Malacco. 1998. Incrimination of Lutzomyia cruzi as a vector of American visceral leishmaniasis. Medical Veterinary Entomology 12: 314-317.

Savani, E. S. M. M.; V. L. B. Nunes; E. A. B. Galati; T. M. Castilho; R. A. Zampieri \& L. M. Floeter-Winter. 2009. The finding of Lutzomyia almerioi and Lutzomyia longipalpis naturally infected by Leishmania spp. in a cutaneous and canine visceral leishmaniases focus in Serra da Bodoquena, Brazil. Veterinary Parasitology 160: 18-24.

São Paulo. 2008. Projeto de desenvolvimento do ecoturismo na região da mata Atlântica (BR-L1013). Informe Ambiental. São Paulo: Governo 
do Estado, Secretaria do Meio Ambiente, Unidade de Coordenação do Projeto de Desenvolvimento do ecoturismo na Região da Mata Atlântica no Estado de São Paulo 69 p. http://www.ekosbrasil.org/anexos/ Informe_Ambiental_revisao_2008.pdf (accessed in 17/07/2009).

Sherlock, I. A. 2003. Importância médico veterinária, p. 15-22. In E. F. Rangel \& R. Lainson (orgs.). Flebotomíneos do Brasil. Rio de Janeiro, Fiocruz, 367 p.

Shimabukuro, P. H. F.; A. M. Marassá \& E. A. B. Galati. 2007. Brumptomyia carvalheiroi sp. nov. (Diptera: Psychodidae: Phlebotominae) from Atlantic Forest domain, São Paulo State, Brazil. Zootaxa: 1637: 4754.

SIGRH (Sistema de Informações para Gerenciamento de Recursos Hídricos do Estado de São Paulo). 2007. http://www.sigrh.sp.gov. Sigrh). br/cgibin/bdhm.exe/procura (05/07/2007).

Souza, N. A.; C. A. Andrade-Coelho; M. L. Vilela \& E. F. Rangel. 2001. The Phlebotominae sand fly (Diptera: Psychodidae) fauna of two rain forest reserves in the State of Rio de Janeiro, Brazil. Memórias do Instituto Oswaldo Cruz 96: 319-324.

Taniguchi, H. H.; J. E. Tolezano; R. Larosa; R. C. Elias \& E. A. B. Galati. 2002. Observações ecológicas de flebotomíneos em área endêmica de leishmaniose tegumentar americana (LTA) no município de Eldorado, Vale do Ribeira, Estado de São Paulo, Brasil, 1996-1997. Sazonalidade e freqüência de L. ayrozai em diferentes ecótopos com animais sentinelas em ambiente florestado. Revista do Instituto Adolfo Lutz 61: 103112.

Tesh, R. B.; B. N. Chaniotis; B. R. Carrera \& K. M. Johnson. 1972. Further studies on the natural host preferences of Panamanian phlebotomines sandflies. American Journal of Epidemiology 95: 88-93.

Young, D. G. \& M. A. Duncan. 1994. Guide to the identification and geographical distribution of Lutzomyia sandflies in Mexico, the West Indies, Central and South America (Diptera: Psychodidae). Memoirs of the American Entomological Institute 54: 1-881. 